\title{
Porous SiC Ceramic Matrix Composite Reinforced by SiC Nanowires with High Strength and Low Thermal Conductivity
}

\author{
RUAN Jing ${ }^{1,2,3}$, YANG Jinshan ${ }^{1,2}$, YAN Jingyi ${ }^{1,2,4}$, YOU Xiao ${ }^{1,2,4}$, WANG Mengmeng ${ }^{1,2,4}$, \\ HU Jianbao ${ }^{1,2}$, ZHANG Xiangyu ${ }^{1,2}$, DING Yusheng ${ }^{1,2}$, DONG Shaoming ${ }^{1,2,5}$
}

\begin{abstract}
(1. State Key Laboratory of High Performance Ceramics \& Superfine Microstructure, Shanghai Institute of Ceramics, Chinese Academy of Sciences, Shanghai 200050, China; 2. Structural Ceramics and Composites Engineering Research Center, Shanghai Institute of Ceramics, Chinese Academy of Sciences, Shanghai 201899, China; 3. School of Physical Science and Technology, ShanghaiTech University, Shanghai 201210, China; 4. University of Chinese Academy of Sciences, Beijing 100039, China; 5. Center of Materials Science and Optoelectronics Engineering, University of Chinese Academy of Sciences, Beijing 100049, China)
\end{abstract}

\begin{abstract}
Porous design of $\mathrm{SiC}$ composites with lightweight, high strength and low thermal conductivity can be obtained by constructing porous silicon carbide nanowires (SiCNWs) network and controlling chemical vapor infiltration (CVI) process. The SiCNWs network with an optimized volume fraction (15.6\%) and uniform pore structure was prepared by mixing SiCNWs and polyvinyl alcohol (PVA) firstly. SiCNWs reinforced porous SiC ceramic matrix composite $(\mathrm{SiCNWs} / \mathrm{SiC})$ with a small uniform pore can be obtained by controlling the CVI parameters. The morphology of the grown SiC matrix, from the spherical particles to the hexagonal pyramid particles, can be influenced by the CVI parameters, such as temperature and reactive gas concentration. The strength of the SiCNWs/SiC ceramic matrix composites reaches (194.3 \pm 21.3$) \mathrm{MPa}$ with a porosity of $38.9 \%$ and thermal conductivity of $(1.9 \pm 0.1) \mathrm{W} /(\mathrm{m} \cdot \mathrm{K})$, which shows the toughening effect and low thermal conductivity design.
\end{abstract}

Key words: $\mathrm{SiC}$ ceramic matrix composite; silicon carbide nanowire; CVI parameter; porosity; thermal conductivity

The temperature of the hypersonic vehicle rises due to the violent friction between the outer wall and the air, while its internal components require a relatively low and stable temperature. To realize the lightweight and low heat transfer efficiency, porous material with inherently half-closed pores can effectively hinder the convective heat transfer of the gas and consequently reduce the thermal conductivity ${ }^{[1]}$. Porous ceramics are relatively high-quality porous material for their lightweight, high-temperature resistance, and excellent chemical corrosion resistance performance, which can be widely used in various extreme environments ${ }^{[2-6]}$. However, the pore structure shows a negative influence on the mechanical strength of the porous ceramics ${ }^{[7-8]}$, in which the brittle failure can be regarded as the major obstacle in its practical application. For the improvement of brittleness, the introduction of reinforcements can be applied to toughen ceramics and may have a positive effect on the toughness of the material. $\mathrm{SiC}$ fibers have been used as the reinforcements of composites for their excellent performance ${ }^{[9-10]}$. SiCNWs possess superior physical and chemical properties as compared with the traditional SiC fibers, and the mechanical strength of SiCNWs is an order of magnitude higher than that of $\mathrm{SiC}$ fibers ${ }^{[11-13]}$. So SiCNWs can be considered as a new reinforcement to replace $\mathrm{SiC}$ fibers to improve the bonding strength between the pore walls for their excellent performance.

A marked risen in the elastic modulus (up to $90 \%$ ) has been reported even with the addition of a small quantity $\left(0.8 \%\right.$ (volume percent)) of nanowires ${ }^{[14]}$. The yield strength of SiCNWs/Al composites can be improved by optimizing the content of SiCNWs of $15 \%, 20 \%$, and $25 \%$ (volume percent) ${ }^{[15]}$. As long as SiCNWs grow on carbon fiber, the interlaminar shear strength of SiCNWs-C/C composites can be enhanced

Received date: 2021-04-07; Revised date: 2021-06-27; Published online: 2021-06-30

Foundation item: National Natural Science Foundation of China (51772310); Chinese Academy of Sciences Key Research Program of Frontier Sciences (QYZDY-SSWJSC031); Innovation Academy for Light-duty Gas Turbine, Chinese Academy of Sciences (CXYJJ20-MS-02)

Biography: RUAN Jing (1993-), male, PhD candidate. E-mail: ruanjing@shanghaitech.edu.cn

阮 景(1993-), 男, 博士研究生. E-mail: ruanjing@shanghaitech.edu.cn

Corresponding author: YANG Jinshan, professor. E-mail: jyang@mail.sic.ac.cn; DONG Shaoming, professor. E-mail: smdong@.sic.ac.cn 杨金山, 研究员. E-mail: jyang@mail.sic.ac.cn; 董绍明, 研究员. E-mail: smdong@mail.sic.ac.cn 
by $32 \%$ as compared with the baseline $e^{[16]}$. The addition of the reinforcing phase can improve the strength of porous ceramic, but the strength of porous ceramic is more sensitive to pore size. Staggered one-dimensional nanowires are expected to build many nanopores, and toughen effect can be realized by reducing the size of the pore ${ }^{[17-19]}$. The low thermal conductivity of air fills the pores and the small size of pores causes less damage to mechanical strength, which makes it a better insulation effect, and possibly existing SiCNWs- pullout is expected to improve the brittleness ${ }^{[20]}$. At present, the introduction of SiCNWs into composite materials is usually based on the in-situ growth method ${ }^{[21-23]}$, and the purity and quality of the introduced SiCNWs are difficult to be controlled. Traditional porous ceramic sintering methods are not suitable for SiCNWs applied in composite, grinding and sintering will destroy nanowire structure ${ }^{[24-25]}$. SiCNWs are hard to be woven like SiC fibers, so it is difficult to prepare a porous SiCNWs network.

In this work, SiCNWs and PVA are mixed to form and fix the SiCNWs network, and the volume fraction and pore structure parameters of the SiCNWs network are controlled by adjusting the ratio of SiCNWs to PVA. The one-dimensional nanostructure of SiCNWs is used to construct a complex and porous network skeleton by controlling CVI parameters to change chemical reaction dynamics. Besides, combining morphology and pore parameters, the influence of different reaction environments on the pore structure is discussed in detail $^{[26-27]}$.

\section{Experimental Procedure}

\subsection{Preparation of SiCNWs dispersion and network skeleton}

Homogenous dispersed SiCNWs (about $10 \mu \mathrm{m}$ in length and $120 \mathrm{~nm}$ in diameter) solution was prepared firstly by mixing SiCNWs (Changsha Sinet Advanced Materials Co., Ltd., China) and dispersant polyvinylpyrrolidone (PVP, Hangzhou Weitong Nanometer Material Co., Ltd., China) in deionized water by sonication (Ningbo Xinzhi Biotechnology Co., Ltd., China) at $300 \mathrm{~W}$ for $100 \mathrm{~min}$. The weight ratio of SiCNWs to PVP to water was controlled at $6: 1: 200$. Then, PVA dispersant was added to disperse SiCNWs with $w(\mathrm{PVA}): w(\mathrm{SiCNWs})=1.3: 1$. After that, the semidry $\mathrm{SiCNW} / \mathrm{PVA}$ mixture was poured into the mold to prepare a film with a size of $30 \mathrm{~mm} \times 30 \mathrm{~mm} \times 0.7 \mathrm{~mm}$, and the SiCNWs formed a network when the solvent was completely evaporated.

\subsection{Preparation of PyC interphase and SiCNWs/ $\mathrm{SiC}$ ceramic matrix composites}

Before the deposition of the $\mathrm{SiC}$ matrix, the SiCNWs/ PVA film was put into a tube furnace for degumming and pyrolytic carbon (PyC) interphase preparation. PVA and PVP were completely removed after $60 \mathrm{~min}$ of pyrolysis at $800{ }^{\circ} \mathrm{C}$ and a complete SiCNWs network was formed in the tube furnace. CVI process was applied to prepare $\mathrm{PyC}$ interphase by the pyrolysis of $\mathrm{CH}_{4}{ }^{[28]}$. The flow ratio of $\mathrm{CH}_{4}$ was controlled at $50 \mathrm{sccm}$ at $3 \mathrm{kPa}$ for several minutes. The $\mathrm{SiC}$ matrix was introduced into the SiCNWs network by pyrogenic decomposition of methyltrichlorosilane (MTS, $\left.\mathrm{CH}_{3} \mathrm{SiCl}_{3}\right)$ as the gaseous precursor, and hydrogen $\left(\mathrm{H}_{2}\right)$ was selected as carrier and dilution gas of MTS. The flow ratio of carrier $\mathrm{H}_{2}$ is $200 \mathrm{sccm}$ and dilute $\mathrm{H}_{2}$ is $60 \mathrm{sccm}$, and the whole pressure of the deposition reaction was controlled at $3 \mathrm{kPa}$ for several hours. The morphology of the deposited $\mathrm{SiC}$ matrix and pore size are influenced by the reaction parameters.

\subsection{Characterization}

The surface and internal morphology of the samples were characterized by scanning electron microscope (SEM; Hitachi SU8220, Japan). The biaxial bending strength was tested by universal material testing machine (UTM, Zhejiang Zili Co., Ltd. Zhejiang, China), in which the samples were prepared into small flat discs with a diameter of $16 \mathrm{~mm}$. The discs were placed on three fixed spheres and formed an equilateral triangle with a side length of $7 \mathrm{~mm}$. The pore parameters were tested by a mercury porosimeter (Micromeritics Instrument Co (Shanghai)., Ltd, America). The porosity of samples throughout the CVI process must be strictly analyzed, which reflects the change of the structure and pore size during the in-situ growth of the $\mathrm{SiC}$ matrix. Thermal diffusivity of the SiCNWs/ $\mathrm{SiC}$ ceramic matrix composite with a size of $12.6 \mathrm{~mm}$ in diameter and $0.7 \mathrm{~mm}$ in thickness was tested under a laser thermal instrument (Laser thermal conductivity meter, TD-79A) from room temperature to $500{ }^{\circ} \mathrm{C}$ at a step of $50{ }^{\circ} \mathrm{C}$. The sample was ground into micronsized powder and filled a container with a diameter of $5 \mathrm{~mm}$ and a height of $18 \mathrm{~mm}$ for specific heat test (MHTC96, Oriental Scientific Instruments Shanghai Import and Export Co., Ltd., France).

\section{Results and discussion}

Fig. 1 shows the morphologies of the SiCNWs net- 
work before and after deposition of the SiC matrix. Fig. 1(a) is the surface morphology of the SiCNWs/ PVA film, it shows that SiCNWs are completely wrapped by PVA. Fig. 1(b) is the original SiCNWs network skeleton, which shows various shapes of SiCNWs and some bulges like fish scales can be found on the nanowire. Fig. 1(c, d) are the surface morphologies of the $\mathrm{SiCNWs} / \mathrm{SiC}$ ceramic matrix composites with a small amount of deposited $\mathrm{SiC}$. The porosity of Fig. $1(\mathrm{c}$, d) is $87.1 \%$ and $84.2 \%$, respectively. The SiCNWs can be found wrapped in $\mathrm{SiC}$ matrix without interphase, as shown in Fig. 1(c). Differently, the grown $\mathrm{SiC}$ matrix aggregates into clusters and shows the state of lumpy particles around SiCNWs with PyC interphase as shown in Fig. 1(d). SiC matrix deposits unevenly on the PyC interphase, which can be attributed to the weak and unstable bonding strength of $\mathrm{SiC}$ and $\mathrm{PyC}$, and consequently the bonding energy of $\mathrm{SiC}$ and $\mathrm{PyC}$ is higher than that of $\mathrm{SiC}$ and SiCNWs. When the system energy supply during MTS pyrolysis is insufficient, the reaction is easy to be oversaturated and the grown $\mathrm{SiC}$ tends to combine with $\mathrm{SiC}$ to reduce the dependence on supplied energy. The PyC interphase is not evenly covered on the SiCNWs as shown in Fig. 1(d). The exposed $\mathrm{SiC}$ with little covered PyC interphase becomes perfect deposition sites for MTS pyrolyzing and attaching, while the following pyrolyzed $\mathrm{SiC}$ matrix tends to grow on the fixed deposition sites and the apparent agglomeration of $\mathrm{SiC}$ can be found. Fig. 1(e, f) are the surface morphologies of the samples without and with $\mathrm{PyC}$ interphase after a long time CVI process. The porosities of Fig. 1(e, f) are $66.2 \%$ and $72.7 \%$, respectively. Fig. 1(e) is surface morphology of the sample without interphase, generated $\mathrm{SiC}$ wraps the SiCNWs and the thickness of the in-situ generated $\mathrm{SiC}$ shell gradually increases which makes the sample denser and denser. While the sample with PyC interphase is shown in Fig. 1(f), the agglomerated $\mathrm{SiC}$ particles gradually grow up to contact each other and compact the sample. Even for a long time CVI process, there exists little $\mathrm{SiC}$ on the $\mathrm{PyC}$ interphase for that $\mathrm{PyC}$ interphase is not an optimal deposition site when the the reaction is oversaturated. Reducing temperature will exacerbate the oversaturation, and the reaction prefers depositing $\mathrm{SiC}$ on the exposed $\mathrm{SiC}$ surface to lower the energy required.

The deposition temperature shows a significant effect on the growth morphology of the $\mathrm{SiC}$ matrix. After a long time of CVI deposition, $\mathrm{SiC}$ matrix deposited at 950, 1030 and $1100{ }^{\circ} \mathrm{C}$ have porosities of $67.3 \%$,
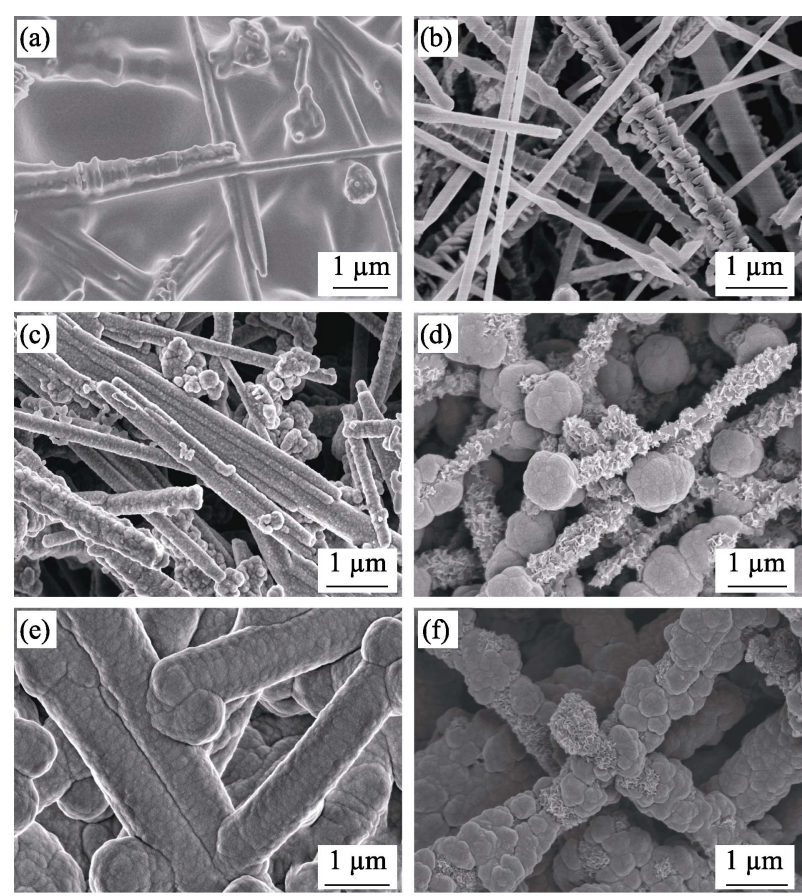

Fig. 1 Surface morphologies of the SiCNWs/PVA film (a), SiCNWs network without $\mathrm{PyC}$ and $\mathrm{SiC}$ deposition (b), surface morphologies of sample without (c) and with (d) PyC interphase after short time CVI process, and without (e) and with (f) $\mathrm{PyC}$ interphase after a long time CVI process

$66.2 \%$ and $63.5 \%$, respectively. As shown in Fig. 2, the $\mathrm{SiC}$ matrix tends to preferentially grow into spherical particles when the temperature is lower than $950{ }^{\circ} \mathrm{C}$, while transforms into a hexagonal pyramidal when the temperature rises to $1030{ }^{\circ} \mathrm{C}$. Subsequently, the hexagonal pyramidal $\mathrm{SiC}$ matrix is still dominated when the temperature rises to $1100{ }^{\circ} \mathrm{C}$, but its particle size is significantly larger than that of the matrix deposited at $1030{ }^{\circ} \mathrm{C}$. Generally, the reaction temperature is an important parameter affecting the growth morphology, which is associated with reaction activity and energy. The pyrolysis of the precursor and the in-situ growth of the $\mathrm{SiC}$ matrix are processes of nucleation and re-growth, and the volume energy and surface energy are major factors to be considered. For the growth of the $\mathrm{SiC}$ matrix, the energy required as follows:

$$
\Delta G=\left(\frac{4 \pi r^{3}}{3}\right) \Delta G_{\mathrm{V}}+4 \pi r^{2} \sigma
$$

Hemispherical particles: $\frac{d_{v}}{d_{s}}=\frac{r}{2}$

$$
\text { Cone particles: } \frac{d_{v_{1}}}{d_{s_{1}}}=\frac{r}{2} \sin \theta
$$

where $\Delta G$ is the total energy required for $\mathrm{SiC}$ deposition, $\Delta G_{\mathrm{V}}$ is the volume energy of $\mathrm{SiC}, \sigma$ is the surface 

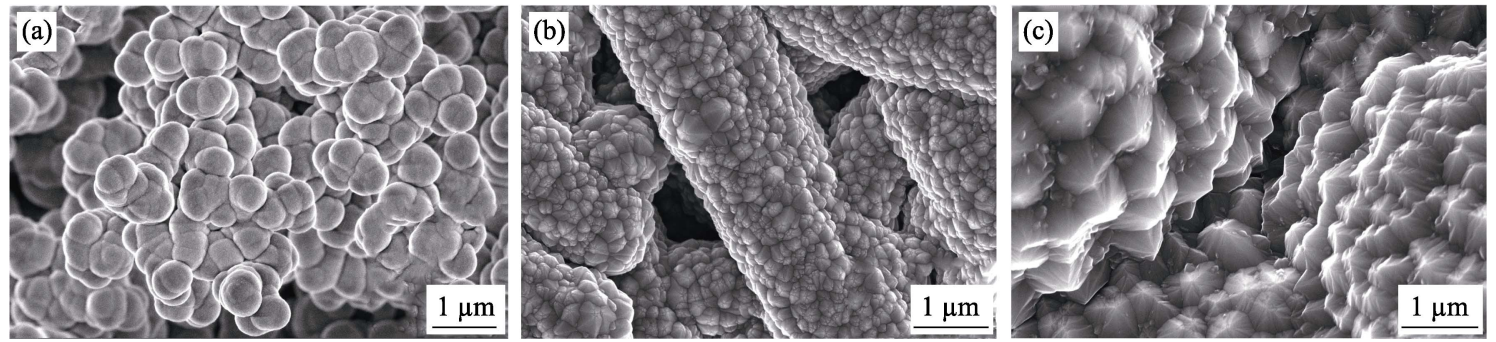

Fig. 2 Growth morphologies of $\mathrm{SiC}$ matrix CVI deposited at temperatures of (a) $950{ }^{\circ} \mathrm{C}$, (b) $1030{ }^{\circ} \mathrm{C}$, and (c) $1100{ }^{\circ} \mathrm{C}$

energy of SiC. $v$ and $S$ are the volume and surface of the grown $\mathrm{SiC}$, respectively. In previous research, there are two growth morphologies of the grown $\mathrm{SiC}$ matrix obtained by the CVI process, including spherical and hexagonal cone shape ${ }^{[29]}$. Under the same growth conditions, the growth of the hexagonal cone shape requires the highest surface energy, while the growth of a spherical shape requires the lowest surface energy $^{[30]}$. Therefore, at low temperature, the $\mathrm{SiC}$ matrix tends to preferentially grow into a spherical shape to reduce the energy required, which can be attributed to the insufficient system energy supply. When the temperature rises, the reaction is not over-saturated, and the spherical $\mathrm{SiC}$ matrix deposition can transform into hexagonal cone deposition. Moreover, the $\mathrm{SiC}$ matrix can also be deposited at the angle between the surfaces of two crystal grains to reduce the energy. So $1030{ }^{\circ} \mathrm{C}$ is chosen as the deposition temperature for the following pore parameter control.

The external surface and fracture surface morphologies of the prepared $\mathrm{SiCNWs} / \mathrm{SiC}$ ceramic matrix composites with various deposition temperatures are shown in Fig. 3. The surfaces of the samples deposited at 1030 and $1100{ }^{\circ} \mathrm{C}$ show dense and little open pores, indicating that the continuous CVI process makes no effort for internal pore filling. As shown in Fig. 3(d), the more convex $\mathrm{SiC}$ spheres can be attributed to the temperature increase that accelerates the pyrolysis of the precursor, and consequently, the $\mathrm{SiC}$ matrix grows directly on the surface of the sample. The crosssection views in Fig. 3(b, e) demonstrate that the sample CVI deopsited at $1030{ }^{\circ} \mathrm{C}$ is denser than that deopsited at $1100{ }^{\circ} \mathrm{C}$, in which the layer thickness of grown $\mathrm{SiC}$ matrix is $(267 \pm 33)$ and $(125 \pm 27) \mathrm{nm}$, respectively. The porosity of the samples CVI deopsited at $1100{ }^{\circ} \mathrm{C}$ shows a porosity of $45.8 \%$, compared with the one CVI deopsited at $1030{ }^{\circ} \mathrm{C}$ of $37.5 \%$. Therefore, the increase in temperature increases the porosity and the densification difference between surface and internal. It can be explained by reaction kinetics that the movement of the precursor MTS in the horizontal direction is mainly determined by pumping force, whether it entered the internal pore of
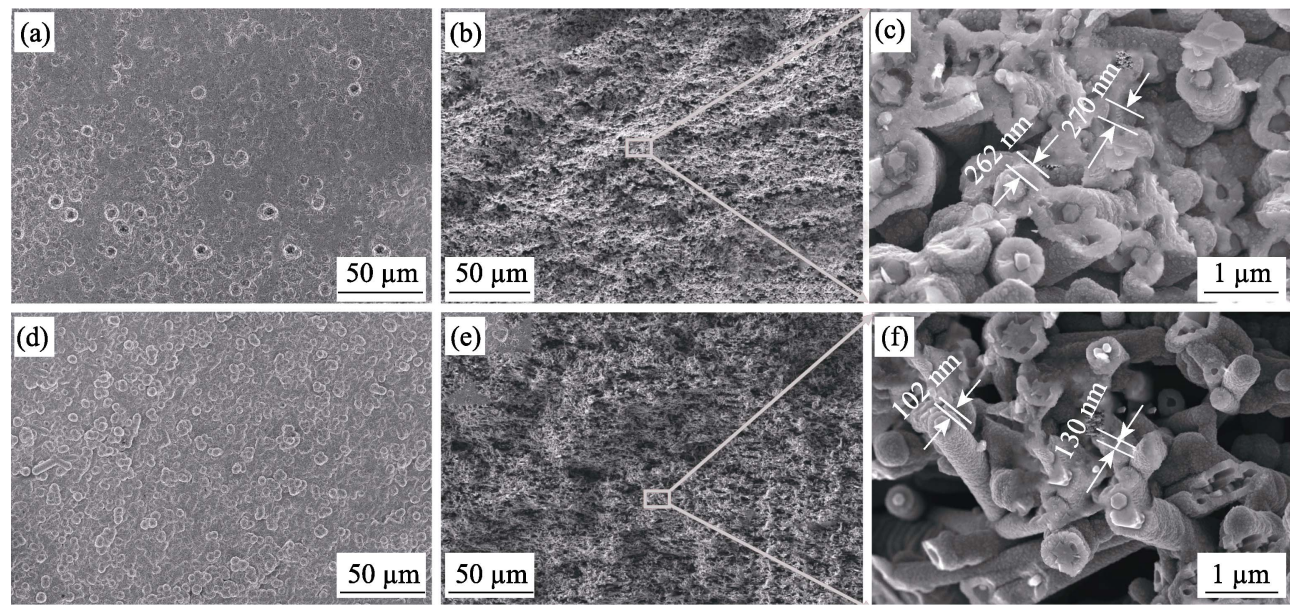

Fig. 3 SEM images of the prepared $\mathrm{SiCNW} / \mathrm{SiC}$ ceramic matrix composites

(a) External surface view of the sample under $8 \mathrm{~h} \mathrm{CVI} \mathrm{process} \mathrm{at} 1030{ }^{\circ} \mathrm{C}$; (b) Fracture surface view and (c) corresponding enlarged region of the sample under $8 \mathrm{~h} \mathrm{CVI} \mathrm{process} \mathrm{at} 1030{ }^{\circ} \mathrm{C}$; (d) External surface view of the sample under $8 \mathrm{~h}$ CVI process at $1100{ }^{\circ} \mathrm{C}$;

(e) Fracture surface view and (f) corresponding enlarged region of the sample under $8 \mathrm{~h} \mathrm{CVI} \mathrm{process} \mathrm{at} 1100{ }^{\circ} \mathrm{C}$ 
the SiCNWs network is influenced by molecular thermal movement. So it caters to Arrhenius formula ${ }^{[31]}$.

$$
\begin{gathered}
\frac{t_{2}}{t_{1}}=\frac{K_{1}}{K_{2}} \\
K=e^{\frac{-E_{a}}{R T}} \\
V=\sqrt{\frac{8 k T}{\pi m}} \\
\frac{L_{2}}{L_{1}}=\frac{V_{2} t_{2}}{V_{1} t_{1}}
\end{gathered}
$$

In which $V_{1}$ and $V_{2}$ are the average molecular thermal motion rates, $K$ is the rate constant that represents the probability of pyrolysis per unit time, $k$ is Boltzmann constant, $E_{\mathrm{a}}$ is the reaction activation energy, $T$ is the temperature of the tube furnace, $m$ is the molecular weight of MTS, $t_{2}$ and $t_{1}$ are the average thermal motion time of MTS before pyrolysis, $L$ is the sum of thermal motion trajectory. $V_{1}$ approximately equals $V_{2}$, so $\frac{L_{2}}{L_{1}}=e^{\frac{-E_{\mathrm{a}}}{R}}\left(\frac{1}{T_{1}}-\frac{1}{T_{2}}\right)$. Reducing temperature means more time left for the process that MTS fully decomposed into $\mathrm{SiC}$, which is considered to that reducing reaction temperature can increase the pyrolysis time of MTS, thus extending the migration distance of MTS and increasing the chance for MTS to enter the internal channel. However, excessively lowering the temperature may change the growth state of the $\mathrm{SiC}$ matrix, or generate easily oxidized free silicon, which will eventually affect the performance of the ceramic matrix composites ${ }^{[32-36]}$. So $1030{ }^{\circ} \mathrm{C}$ is chosen as the deposition temperature for the following control of pore parameter, which can reduce the densification difference between surface and internal and improve the density of the composite.

The distributions of the pore sizes of the as-prepared $\mathrm{SiCNWs} / \mathrm{SiC}$ ceramic matrix composites with different porosities is shown in Fig. 4. The in-situ deposited SiC wraps SiCNWs and the thickness of the deposited $\mathrm{SiC}$ shell increases. SiC can effectively fill the pores, and the pore size and porosity of the composites decrease. Besides, the proportion of small pores increases rapidly, which indicates that the big pores are filled into small pores. Compared with the sample with a porosity of $76.7 \%$ (volume percent), the sample with a porosity of $61.9 \%$ (volume percent) shows more small pores due to the greater slope. As the density increases, the volume fraction of small pores increases. Compared with the sample with a porosity of $38.9 \%$ (volume percent), the volume

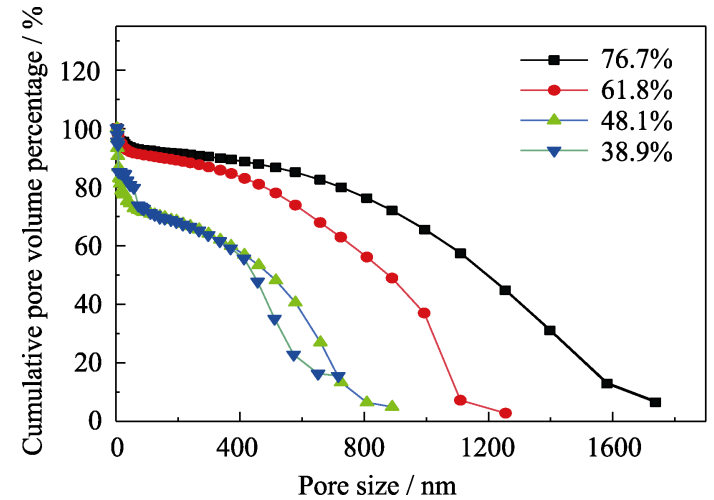

Fig. 4 Cumulative pore volume distribution with different pore size

fraction of small pores of the sample with a porosity of $48.1 \%$ (volume percent) is higher. With the densification increasing, the proportion of small pores decreases. The reason is that MTS molecules fail to flow through small pores and MTS molecules prefer to attach to the pore walls, which accelerates the blockage of the small pores, and the pores with small size decrease. The reduction of the small pores leads to the volume fraction of the small pores decreases dramatically. Therefore, the change of the pore structure can be monitored by the pore parameters.

The porous structure shows a significant impact on the strength and thermal conductivity of the as-prepared $\mathrm{SiCNWs} / \mathrm{SiC}$ ceramic matrix composites. As shown in Fig. 5, the biaxial bending strength increases with the decrease of the porosity. The in-situ grown $\mathrm{SiC}$ wraps the SiCNWs, which results in the thickness of the in-situ generated $\mathrm{SiC}$ shell increasing and gradually making the network form a whole, and loading can effectively transfer between SiCNWs. The SiC deposition effectively enhances the connection of SiCNWs. The improvement of the strength increases as the amount of in-situ grown $\mathrm{SiC}$ increases, and the reason is that pore size can be treated as the size of the crack, and the reduction of the pore size is more meaningful for the strength improvement in the later stage. While the improvement of porosity on thermal conductivity decreases as the porosity decreases. The reason is that the thermal conductivity of the composite mainly depends on the heat conduction of the internal SiCNWs. In the early stage of the CVI process, $\mathrm{SiC}$ deposited at the cross-links of the SiCNWs, which enhanced the heat conduction between SiCNWs, and the thermal conductivity of the composite increases. As the thickness of the deposited $\mathrm{SiC}$ shell increase, the cross-section of the heat conduction channel increases. The heat transfer effect of $\mathrm{SiC}$ is less than that 


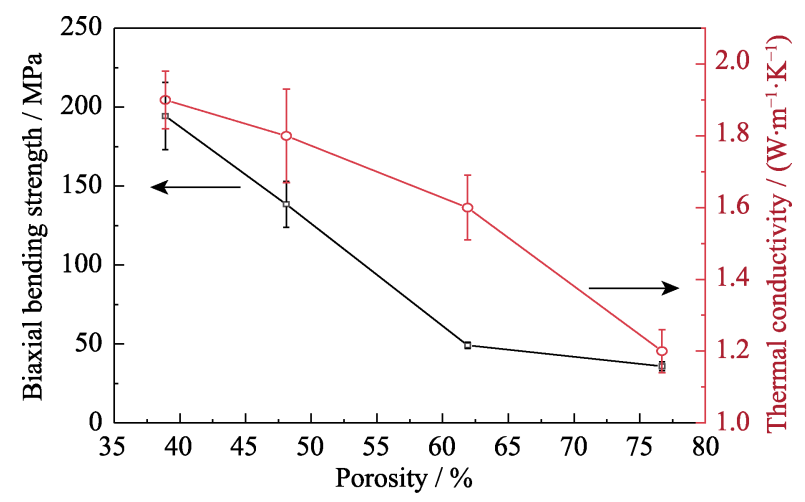

Fig. 5 Changes of strength and thermal conductivity with porosity of porous $\mathrm{SiCNWs} / \mathrm{SiC}$ ceramic matrix composite

of SiCNWs, therefore the improvement of thermal conductivity decreases in the later stage of deposition. Compared with thermal conductivity, strength is more sensitive to the decrease of porosity. By adjusting the deposition temperature, the densification difference between surface and internal reduces, and the pore size of the composite reduces. Through optimizing pores parameter, the porous $\mathrm{SiCNWs} / \mathrm{SiC}$ ceramic matrix composite with small size pore hopes a high strength. Through introducing PyC interphase into SiCNWs/ $\mathrm{SiC}$ ceramic matrix composite, the composite shows a good mechanical enhancement effect. By introducing SiCNWs into the $\mathrm{SiC}$ matrix, the strength of the $\mathrm{SiCNWs/SiC}$ composite significantly improves. The performance and parameters of other porous materials are compared in Table 1. Comprehensive consideration of the strength and thermal conductivity, the composite of this work shows high strength and low thermal conductivity, and the $\mathrm{SiCNWs} / \mathrm{SiC}$ ceramic matrix composite with a porosity of $38.9 \%$ presents a strength of $(194.3 \pm 21.3) \quad \mathrm{MPa}$ and a thermal conductivity of $(1.9 \pm 0.1) \mathrm{W} /(\mathrm{m} \cdot \mathrm{K})$.

Fig. 6 is the biaxial bending strength of the porous SiCNWs/SiC ceramic matrix with/without PyC interphase. The composite without interphase shows a strength of (138.5 \pm 14.7$) \mathrm{MPa}$, and the composite with PyC interphase shows a higher strength of (194.3 \pm
21.3) MPa. Through introducing PyC interphase into $\mathrm{SiCNWs} / \mathrm{SiC}$ ceramic matrix composite, the strength increased by $40.3 \%$.

The section morphologies of the two samples with/ without $\mathrm{PyC}$ interphase are shown in Fig. 7. The porosity of the composites with or without $\mathrm{PyC}$ interphase are all about 38\%. As for the specimen with $\mathrm{PyC}$ interphase, there exists a longer pull-out length of SiCNWs on the fracture surface, and the fracture shows a certain cut angle compared with the flat fracture of the sample without $\mathrm{PyC}$ interphase. The moderate bonding strength between $\mathrm{PyC}$ interphase and $\mathrm{SiC}$ matrix and SiCNWs makes the nanowires easy debonded and pulled out from the matrix. The extended propagation path of the crack and the increased pull-out length of the nanowire demonstrated that more energy absorbed during the fracture process and PyC interphase contributes to the enhancement effect of SiCNWs even in the porous composite.

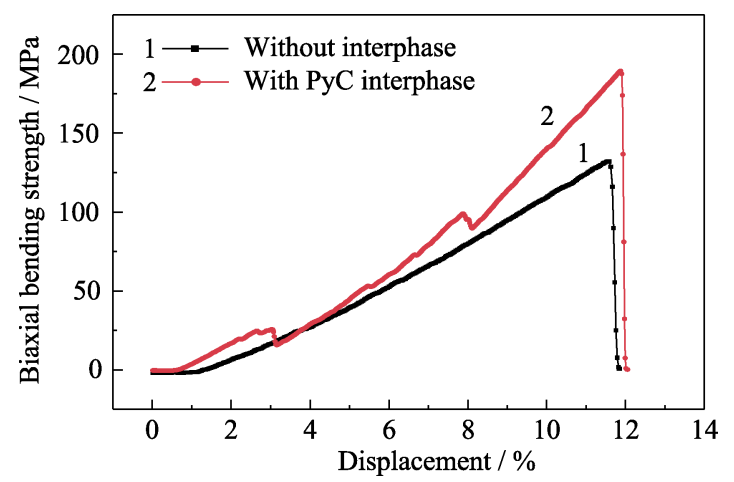

Fig. 6 Biaxial bending strength of the $\mathrm{SiCNW} / \mathrm{SiC}$ ceramic matrix composite with or without $\mathrm{PyC}$ interphase
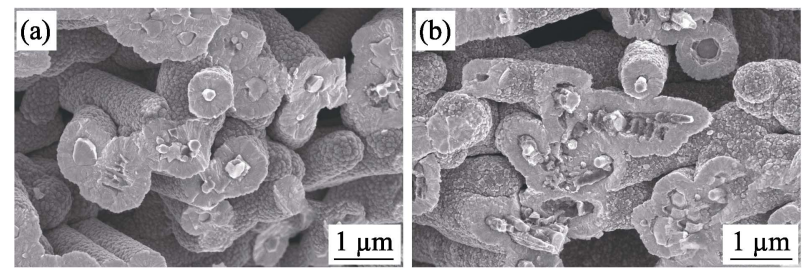

Fig. 7 Fracture morphologies of the $\mathrm{SiCNW} / \mathrm{SiC}$ ceramic matrix composite

(a) Without interphase; (b) With PyC interphase

Table 1 Strength and thermal conductivity of different materials

\begin{tabular}{lcccc}
\hline \multicolumn{1}{c}{ Material } & Porosity $/ \%$ & Strength $/ \mathrm{MPa}$ & Thermal conductivity $/\left(\mathrm{W} \cdot \mathrm{m}^{-1} \cdot \mathrm{K}^{-1}\right)$ & $\mathrm{Ref}$. \\
\hline Porous $\mathrm{SiC}-\mathrm{SiO}_{2}$ ceramic & $\sim 72$ & $\sim 2.7$ & 0.066 & {$[37]$} \\
$\mathrm{Sc}-$ doped porous $\mathrm{SiC}$ ceramic & $\sim 61$ & 10.5 & 7.700 & {$[38]$} \\
Porous $\mathrm{Al}_{2} \mathrm{O}_{3}-\mathrm{SiC}$ & $\sim 38$ & 28.0 & - & {$[39]$} \\
Porous $\mathrm{ZrB}_{2}-\mathrm{SiC}$ ceramics & $\sim 59$ & $\sim 78.0$ & - & {$[40]$} \\
Porous $\mathrm{SiC}$ ceramic & $\sim 40$ & $\sim 10.7$ & 1.900 & {$[41]$} \\
Porous $\mathrm{SiCNW} / \mathrm{SiC}$ ceramic matrix composite & $\sim 39$ & $\sim 194.3$ & 1.600 & This work \\
Porous $\mathrm{SiCNW} / \mathrm{SiC}$ ceramic matrix composite & $\sim 62$ & $\sim 49.0$ & This work \\
\hline
\end{tabular}




\section{Conclusion}

The porous SiCNWs network framework with a volume fraction of $15.6 \%$ was prepared by mixing SiCNWs and PVA colloids. Through controlling CVI parameters to change the chemical reaction dynamics, two different in-situ grown $\mathrm{SiC}$ micro morphologies were obtained. Under different chemical reaction kinetics, the density and pore structure parameters of the porous $\mathrm{SiCNWs} / \mathrm{SiC}$ ceramic matrix composite are also very different. The $\mathrm{SiCNW} / \mathrm{SiC}$ ceramic matrix composite with a porosity of $38.9 \%$ possesses thermal conductivity of $(1.9 \pm 0.1) \mathrm{W} /(\mathrm{m} \cdot \mathrm{K})$ and biaxial bending strength of (194.3 \pm 21.3$) \mathrm{MPa}$.

\section{Reference:}

[1] LI S, ZENG X, CHEN H, et al. Porous hexagonal boron nitride nanosheets from $\mathrm{g}-\mathrm{C}_{3} \mathrm{~N}_{4}$ templates with a high specific surface area for $\mathrm{CO}_{2}$ adsorption. Ceramics International, 2020, 46(17): 27627-27633.

[2] SARAVANAN S, CHIDAMBARAM R K, GEO V E. An experimental study to analyze influence of porous media combustor on performance and emission characteristics of a DI diesel engine. Fuel, 2020, 280: 118645-1-8.

[3] BICY K, KALARIKKAL N, STEPHEN A M, et al. Facile fabrication of microporous polypropylene membrane separator for lithium-ion batteries. Materials Chemistry and Physics, 2020, 255: 123473-1-9.

[4] PAN B, CHEN J, ZHANG F, et al. Porous $\mathrm{TiO}_{2}$ aerogel-modified $\mathrm{SiC}$ ceramic membrane supported $\mathrm{MnO}_{x}$ catalyst for simultaneous removal of NO and dust. Journal of Membrane Science, 2020, 611: 118366-1-10.

[5] SONG X, JIAN B, JIN J. Preparation of porous ceramic membrane for gas-solid separation. Ceramics International, 2018, 44(16): 20361-20366.

[6] WANG Z, PAN Z. Preparation of hierarchical structured nano-sized/ porous poly (lactic acid) composite fibrous membranes for air filtration. Applied Surface Science, 2015, 356: 1168-1179.

[7] LIU X, MARTIN C L, BOUVARD D, et al. Strength of highly porous ceramic electrodes. Journal of the American Ceramic Society, 2011, 94(10): 3500-3508.

[8] HUO W, ZHANG X, CHEN Y, et al. Mechanical strength of highly porous ceramic foams with thin and lamellate cell wall from particle-stabilized foams. Ceramics International, 2018, 44(5): 5780-5784.

[9] SAUCEDO M L, LOWE T, ZHAO S, et al. In situ observation of mechanical damage within a $\mathrm{SiC}-\mathrm{SiC}$ ceramic matrix composite. Journal of Nuclear Materials, 2016, 481: 13-23.

[10] SONG C, LIU X, YE F, et al. Mechanical and dielectric properties of $\mathrm{SiC}_{\mathrm{f}} / \mathrm{BN} / \mathrm{SiBCN}$ composites via different synthesis technologies. Journal of the European Ceramic Society, 2019, 39(14): 4417-4423.

[11] WANG H, ZHOU X, YU J, et al. Fabrication of $\mathrm{SiC}_{\mathrm{f}} / \mathrm{SiC}$ composites by chemical vapor infiltration and vapor silicon infiltration.
Materials Letters, 2010, 64(15): 1691-1693.

[12] WONG E W, SHEEHAN P E, LIEBER C M. Nanobeam mechanics: elasticity, strength, and toughness of nanorods and nanotubes. Science, 1997, 277(5334): 1971-1975.

[13] ZHANG Y, HAN X, ZHENG K, et al. Direct observation of superplasticity of beta-SiC nanowires at low temperature. Advanced Functional Materials, 2007, 17(17): 3435-3440.

[14] VIVEKCHAND S R C, RAMAMURTY U, RAO C N R. Mechanical properties of inorganic nanowire reinforced polymer-matrix composites. Nanotechnology, 2006, 17(11): 344-S350.

[15] XIN L, YANG W, ZHAO Q, et al. Strengthening behavior in SiC nanowires reinforced pure Al composite. Journal of Alloys and Compounds, 2017, 695: 2406-2412.

[16] SHEN Q L, LI H J, LI L, et al. SiC nanowire reinforced carbon/ carbon composites with improved interlaminar strength. Materials Science and Engineering: A, 2016, 651: 583-589.

[17] DONG L H, ZHANG H J, ZHANG J, et al. Carbon nanotube modified sepiolite porous ceramics for high-efficient oil/water separation. Journal of Inorganic Materials, 2020, 35(6): 689-696.

[18] ZHANG K J, YADAV A, KIM K H, et al. Thermal and electrical transport in ultralow density single-walled carbon nanotube networks. Advanced Materials, 2013, 25(21): 2926-2931.

[19] ZHAO X, HUANG C, LIU Q, et al. Thermal conductivity model for nanofiber networks. Journal of Applied Physics, 2018, 123(8): 085103-1-10.

[20] MA R, CHENG X, YE W. SiC fiber and yttria-stabilized zirconia composite thick thermal barrier coatings fabricated by plasma spray. Applied Surface Science, 2015, 357: 407-412.

[21] ZHUANG L, FU Q G, LIU T Y, et al. In-situ PIP-SiC NWstoughened $\mathrm{SiC}-\mathrm{CrSi}_{2}-\mathrm{Cr}_{3} \mathrm{C}_{2}-\mathrm{MoSi}_{2}-\mathrm{Mo}_{2} \mathrm{C}$ coating for oxidation protection of carbon/carbon composites. Journal of Alloys and Compounds, 2016, 675: 348-354.

[22] CHU Y, LI H, FU Q, et al. Toughening by $\mathrm{SiC}$ nanowires in a dense SiC-Si ceramic coating for oxidation protection of $\mathrm{C} / \mathrm{C}$ composites. Journal of the American Ceramic Society, 2012, 95(11): 3691-3697.

[23] WANG D, XUE C, BAI H, et al. Silicon carbide nanowires grown on graphene sheets. Ceramics International, 2015, 41(4): 5473-5477.

[24] NGUYEN V H, DELBARI S A, AHMADI Z, et al. Electron microscopy characterization of porous $\mathrm{ZrB}_{2}$-SiC-AlN composites prepared by pressureless sintering. Ceramics International, 2020, 46(16): $25415-25423$.

[25] LI X, YAO D, ZUO K, et al. Microstructure and permeability of porous YSZ ceramics fabricated by freeze casting of oil-in-water suspension. Journal of the European Ceramic Society, 2020, 40(15): 5845-5851.

[26] FITZER E, HEGEN D. Chemical vapor-deposition of siliconcarbide and silicon-nitride-chemistrys contribution to modern silicon ceramics. Angewandte ChemieInternational Edition, 1979, 18(4): 295-304.

[27] NASLAIN R, ROSSGNOL J Y, HAGENMULLER P, et al. Synthesis and properties of new composite-materials for high-temperature applications based on carbon-fibers and $\mathrm{C}-\mathrm{SiC}$ or $\mathrm{C}-\mathrm{TiC}$ hybrid matrices. Revue De ChimieMinerale, 1981, 18(5): 544-564.

[28] RUAN J, YANG J S, DONG S M, et al. Interfacial optimization of $\mathrm{SiC}$ nanocomposites reinforced by $\mathrm{SiC}$ nanowires with high volume fraction. Journal of the American Ceramic Society, 2019, 102(9): 5033-5037.

[29] ZHU Y, ZHANG Y, YAN L S. Interface between multi-layered 
CVD SiC coating and its graphite substrate. Equipment Environmetal Engineering, 2019, 16(10): 59-63.

[30] CHIN J, GANTZEL P K, HUDSON R G. The structure of chemical vapor deposition sillicon carbide. Thin Solid Films, 1977, 40: $57-72$.

[31] MASLOV M M, OPENOV L A, PODILIVAEV A I. On the vineyard formula for the pre-exponential factor in the Arrhenius law. Physics of the Solid State, 2014, 56(6): 1239-1244.

[32] TIEGS T N. Fission product Pd-SiC interaction in irradiated coated-particle fuels. Nuclear Technology, 2017, 57(3): 389-398.

[33] KINGON A I, LUTZ L J, LIAW P, et al. Thermodynamic calculations for the chemical vapor deposition of silicon carbide. Journal of the American Ceramic Society, 1983, 66(8): 558-566.

[34] KAZUO M, KOUSAKU F. Structure of chemically vapour deposited silicon carbide for coated fuel particles. Journal of Materials Science, 1998, 23: 699-706.

[35] BYUNG J C, DONG W P, DAI R K. Chemical vapour deposition of silicon carbide by pyrolysis of methylchlorosilanes. Journal of Materials Science Letters, 1997, 16: 33-36.

[36] HAN D Y, MEI H, XIAO S S, et al. Porous $\mathrm{SiC}_{\mathrm{nw}} / \mathrm{SiC}$ ceramics with unidirectionally aligned channels produced by freeze-drying and chemical vapor infiltration. Journal of the European Ceramic Society, 2017, 37(3): 915-921.

[37] KANG E S, KIM Y W, NAM H. Multiple thermal resistance induced extremely low thermal conductivity in porous $\mathrm{SiC}_{-} \mathrm{SiO}_{2}$ ceramics with hierarchical porosity. Journal of the European Ceramic Society, 2021, 41(2): 1171-1180.

[38] KULTAYEVA S, KIM Y W, SONG I H. Effects of dopants on electrical, thermal, and mechanical properties of porous $\mathrm{SiC}$ ceramics. Journal of the European Ceramic Society, 2021, 41(7): 4006-4015.

[39] DEY A, KAYAL N, CHAKRABARTI O, et al. Studies on processing of layered oxide-bonded porous $\mathrm{SiC}$ ceramic filter materials. International Journal of Applied Ceramic Technology, 2021, 18(3): 869-879.

[40] QI Y S, JIANG K, ZHOU C L, et al. Preparation and properties of high-porosity $\mathrm{ZrB}_{2}$-SiC ceramics by water-based freeze casting. Journal of the European Ceramic Society, 2021, 41(4): 2239-2246.

[41] RAJPOOT S, HA J H, KIMY W. Effects of initial particle size on mechanical, thermal, and electrical properties of porous SiC ceramics. Ceramics International, 2021, 47(6): 8668-8676.

\section{碳化硅纳米线增强多孔碳化硅陶瓷基复合材料的制备}

$$
\begin{gathered}
\text { 阮 景 }{ }^{1,2,3} \text {, 杨金山 }{ }^{1,2} \text {, 间静怡 }{ }^{1,2,4} \text {, 游 萧 }{ }^{1,2,4} \text {, 王萌萌 }{ }^{1,2,4} \text {, } \\
\text { 胡建宝 }^{1,2} \text {, 张翔宇 }{ }^{1,2} \text {, 丁王生 }{ }^{1,2} \text {, 董绍明 } 1,2,5
\end{gathered}
$$

(1. 中国科学院 上海硅酸盐研究所高性能陶瓷和超微结构国家重点实验室, 上海 200050; 2. 中国科学院上海硅 酸盐研究所结构陶瓷及复合材料工程研究中心, 上海 201899; 3. 上海科技大学 物质科学与技术学院, 上海 201210; 4. 中国科学院大学, 北京 100039; 5. 中国科学院大学 材料科学与光电工程中心, 北京 100049)

摘 要: 构建多孔碳化硅纳米线(SiCNWs)网络并控制化学气相渗透(CVI)过程, 可设计并获得轻质、高强度和低导 热率 $\mathrm{SiC}$ 复合材料。首先将 $\mathrm{SiCNWs}$ 和聚乙烯醇(PVA)混合, 制备具有最佳体积分数(15.6\%)和均匀孔隙结构的 $\mathrm{SiCNWs}$ 网络; 通过控制 CVI 参数获得具有小而均匀孔隙结构的 $\mathrm{SiCNWs}$ 增强多孔 $\mathrm{SiC}(\mathrm{SiCNWs} / \mathrm{SiC})$ 陶瓷基复合 材料。 $\mathrm{SiC}$ 基体形貌受沉积参数(如温度和反应气体浓度)的影响, 从球状颗粒向六棱雉颗粒形状转变。 $\mathrm{SiCNWs} / \mathrm{SiC}$ 陶瓷基复合材料的孔隙率为 $38.9 \%$ 时, 强度达到 $(194.3 \pm 21.3) \mathrm{MPa}$, 导热系数为 $(1.9 \pm 0.1) \mathrm{W} /(\mathrm{m} \cdot \mathrm{K})$, 显示出增韧效 果, 并具有低导热系数。

关 键 词: $\mathrm{SiC}$ 基复合材料; 碳化硅纳米线; CVI 参数; 孔隙率; 热导率

中图分类号: TQ174 文献标志码: A 